\title{
Provide a model to identify the effect of the occurrence of business cycles on financial uncertainty in the stock market Developed countries
}

\section{Proporcionar un modelo para identificar el efecto de la ocurrencia de ciclos económicos sobre la incertidumbre financiera en el mercado de valores Países desarrollados}

\author{
Hossein Shirbandi \\ Department of Accounting, Sanandaj Branch, Islamic Azad University, Sanandaj, Iran \\ ORCID: https://orcid.org/0000-0002-2983-2658 \\ Farzad Moayeri \\ Department of Accounting, Sanandaj Branch, Islamic Azad University, Sanandaj, Iran \\ ORCID: https://orcid.org/0000-0002-1188-5137 \\ Ataullah Mohammadi Malqarni \\ Department of Accounting, Sanandaj Branch, Islamic Azad University, Sanandaj, Iran \\ ORCID: https://orcid.org/0000-0003-4888-4848
}

*Correspondence

Email: F.Moayeri46@gmail.com
Cite as:

Shirbandi, H., Moayeri, F., \& Mohammadi, A. (2021). Provide a model to identify the effect of the occurrence of business cycles on financial uncertainty in the stock market Developed countries. Propósitos y Representaciones, 9 (SPE1), e878. Doi: http://dx.doi.org/10.20511/pyr2021.v9nSPE1.878 


\section{Summary}

The main purpose of this study is to provide a model to identify the effect of the occurrence of business cycles on financial uncertainty in the stock market of developed countries. This research is an experimental research and panel data has been used to test the hypothesis. The statistical population of the study is developed countries. We grouped the countries based on high per capita income according to the UN Human Development Report. Data were also collected from the World Bank and 21 developed countries were selected as the sample size. According to the results of coefficients of independent variables (financial leverage, interest rate, inflation, time, recessionary business cycles and boom business cycles) which are all significant, ie their P-VALUE is less than 0.05 , so we can conclude a significant effect. On financial uncertainty (variance of $S \& P$ index growth rate). Also, considering that the coefficient of determination of the regression model (R2) is equal to 0.984 and is close to the number one, that is, the Fisher test (F) is significant (its probability is less than 0.05 ), so the regression model is justifiable and acceptable. Hypothesis $\mathrm{H} 0$ is therefore rejected and Hypothesis $\mathrm{H} 1$ is accepted with $95 \%$ probability, or in other words, business cycles have a significant effect on financial uncertainty in the stock market of developed countries.

Keywords: Recessionary business, financial uncertainty, Index of growth rate variance S\&P

\section{Resumen}

El objetivo principal de este estudio es proporcionar un modelo para identificar el efecto de la ocurrencia de ciclos económicos sobre la incertidumbre financiera en el mercado de valores de los países desarrollados. Esta investigación es una investigación experimental y se han utilizado datos de panel para probar la hipótesis. La población estadística del estudio son países desarrollados. Agrupamos a los países según el alto ingreso per cápita de acuerdo con el Informe de Desarrollo Humano de la ONU. También se recopilaron datos del Banco Mundial y se seleccionaron 21 países desarrollados como tamaño de muestra. De acuerdo con los resultados de los coeficientes de variables independientes (apalancamiento financiero, tasa de interés, inflación, tiempo, ciclos económicos recesivos y ciclos económicos de auge) que son todos significativos, es decir, su P-VALUE es menor a 0.05 , por lo que podemos concluir un efecto significativo. Sobre la incertidumbre financiera (varianza de la tasa de crecimiento del índice S\&P). Además, considerando que el coeficiente de determinación del modelo de regresión (R2) es igual a 0.984 y se acerca al número uno, es decir, la prueba de Fisher $(\mathrm{F})$ es significativa (su probabilidad es menor a 0.05), por lo que la regresión el modelo es justificable y aceptable. Por tanto, se rechaza la hipótesis H0 y se acepta la hipótesis $\mathrm{H} 1$ con un 95\% de probabilidad, es decir, los ciclos económicos tienen un efecto significativo sobre la incertidumbre financiera en el mercado de valores de los países desarrollados.

Palabras clave: Negocio recesivo, Incertidumbre financiera, Índice de variación de la tasa de crecimiento S\&P

\section{Introduction}

The most important goal of a capital structure policy is to determine the composition of financial resources in order to maximize shareholder wealth, companies can raise the capital they need from both internal and external sources. The requirement for financing from internal sources is the company's past profitability, and the accumulation of past profits is a suitable source for financing the company. Financing from external sources can also be done through 
debts (including a range of bank loans, bonds, leases, etc.) or shareholders' equity (including current ordinary and privileged shareholders) and potential investors who are interested in investing in the company (Azinfar et al., 2015). Raising capital through any of these forms of financing has benefits and costs for the company acquiring the capital. High debt ratio for the company , from the analysts' point of view, are more risky, this issue appears in its acute form when the company is short of liquidity and is unable to pay interest on loans taken from creditors, and this is where the issue of the financial crisis and ultimately bankruptcy comes into play. However, financing through debt creation is an advantage for this type of financing because creditors have no voting rights in the company's decisions and usually have no control over the company. On the other hand, because profit expense on debt is a tax-eligible expense, it is the most important advantage of a company's debt. Financing through equity is also one of the most important advantages of this type of financing because it does not pay interest expenses and, more importantly, it does not have a specific maturity to repay the capital principal (shareholders' share). However, the costs of issuing shares and changing the composition of the company's ownership may be considered disadvantages of this type of financing (Imam Verdi et al., 2014). There are many definitions of the business cycle, but almost all definitions have similar meanings. For this reason, there has been less debate on this issue. Burns and Mitchell ("The business cycle is a kind of regular fluctuations in the macroeconomic activities of countries, which are mostly organized by businesses"). A cycle begins with a period of economic prosperity that occurs simultaneously in multiple economic activities and leads to a period of recession and contraction. This series of changes is repeated over and over again, but they are not regular and periodic. Companies need to invest in their assets to generate cash flow and to earn this cash, they have to finance from inside and outside the company (Anna et al., 2015). The only way to finance from within the company is to use the accumulation of undistributed profit in the company's profitability periods. External financing methods include two different types of debt acquisition through borrowing from banks, financial institutions and the issuance of participation bonds, and another way is the issuance of new shares on the stock exchange. Financing the method of issuing shares is more expensive than using debt, but excessive use of debt increases financial uncertainty (Minooi and Ismaili, 2016). The change in earnings per share is due to the change in the fixed financial cost and includes the uncertainty of cessation of activity and the uncertainty of normal fluctuations of each share. Therefore, companies are forced to choose a capital structure whose return increases earnings per share and has the least possible financial uncertainty (Tehrani, 2008). The stock market is an important and vital part of the whole economy. It is clear that there is a strong link between the stock market and the economy. If the economic conditions are unfavorable, the performance of most companies and consequently the stock market will be weak. Conversely, if the economic conditions are right, the performance of companies will be better and as a result, the optimal economic conditions in the stock market will be crystallized. If we look at the economy and the activity of economic units in the form of business cycle, we see that the business cycle has a special framework, that is, it starts from one place, reaches its peak and then ends. Thus, economic activity begins in a state of recession, goes through a stage of development, and then declines and waits for a resurgence (Albiti, 2011). The stock market and the business cycle are closely related, historically, common stock has been one of the important indicators of the business cycle, so we have to look for a complex relationship. The market and the economy are closely related, according to the available evidence, stock prices often change before the state of the economy changes. It is clear that the market is showing negative signs of future economic activity, especially in times of recession and it is important to note that the market can reflect negative signs of economic conditions. However, the market's ability to predict economic 
prosperity is better than its ability to predict economic crises (Management of investment development culture of Tehran Stock Exchange, Bita). Given the above, the main concern of the research is to design a model to identify the effect of business cycles on financial uncertainty in the stock market of developed countries.

\section{Literature and research background}

Periods of increase in economic activity are typically called periods of prosperity and periods of decrease in economic activity are called recession or recession. The combination of booms and busts, that is, the combination of decrease and increase in economic activity, is called business cycles. Business cycles include two point of views that are historically the best, the old perspective and the new perspective.

In the old point of view, people like Mitchell, Dornbusch, Fisher, Startz, Keith China, Jaglar, Kuznets, and Kondratiev believed that business cycles were non-random and regular while in the new point of views, according to Roemer, business cycles are random and irregular.

According to Arthur Burns and Wesley Mitchell (1946) definition, "business cycles are a type of fluctuation that occurs at the macro level of economic activity. A cycle contains a boom that occurs almost simultaneously in many economic activities and then a recession. Almost the same is seen in most economic activities. This arrangement is a frequent but irregular change". What variables are selected and what interdependence or priority is interrelated has been the subject of much research over the years. The most important result of the above definition is that business cycles are not based on changes in one variable (such as GDP) rather, it is defined in terms of a range of economic variables. During the boom, not only does production increase, but employment also increases and unemployment decreases and if the boom is too fast, inflation will rise. In contrast, during a recession, the production of goods and services decreases, employment decreases, and unemployment increases.

Kaviani et al. (2015), in a study entitled The effect of monetary base shocks on the stock price returns of listed companies (DSGE approach), the results of their research show that the monetary base shock first has a positive effect on the stock price return of companies and then returns to its equilibrium and stable state in subsequent periods by reducing this shock. Also, the investment shock due to the greater offering of companies' shares in the capital market first reduces the stock price return because more shares are offered in the market ${ }_{s}$ but in the following periods, the stock price will increase due to the expected profitability of these investments, and consequently the price return will increase. Afshari et al. (2015), based on the results of examining the instantaneous reaction functions of variables to stock market shock, show that the shock of the total stock price index had a negligible effect on output and inflation variables that this could be due to the small size of the stock market in Iran. Finally, by finding the optimal coefficients for the inflation gap, production and the total stock price index and welfare losses of the central bank under each of the scenarios, it was concluded that first, the central bank must add more value to inflation in its response functions; Second, a scenario in which the value of the total stock price index gap is zero has less welfare losses, therefore, the central bank's reaction to the gap in the total stock price index will lead to a decrease in social welfare. Therefore, it is recommended that the central bank does not intervene by reducing the money supply in the context of the stock market boom. Hosseini Sarani et al. (2017), in an article entitled "Study of the effect of financial performance and business cycle on the capital structure of companies operating in the Tehran Stock Exchange". The results of their research 
showed that there was a direct relationship between liquidity (current ratio) or the ability to repay debt and cover the cost of the company in the short term with the financial structure. In addition, there was a direct relationship between company size and age (company level characteristics) and performance (company profitability, turnover and exports) and an inverse relationship between business cycles and corporate capital structure. That is, in a recession, companies are more inclined to use external resources and debt to finance themselves and in a state of economic prosperity, they are more inclined to use internal resources, such as accumulated profits.

Delo and et al. (2017), in an article entitled "The effect of the business cycle on the relationship between profitability and financial lever" during the period 2001-2005 found that the results of examining the relationship between capital structure and profitability during the recession show a significant inverse interaction of profitability on capital structure. Examining the relationship between capital structure and profitability during the boom period also indicates a negative and significant effect of capital structure on profitability. The boom years coincided with the period of organizing the stock market information situation and the beginning of a significant growth trend in the publication of periodic reports, the physical development of the capital market, the opening of OTC markets and thus reducing information asymmetry which in turn increases the company's willingness to issue shares and reduce borrowing and, consequently, reduce the debt-to-equity ratio. Alexander Korov and Raluca Stan (2018), in a study entitled "Monetary Policy Uncertainty and the Market Response to Macroeconomic News" using daily futures data, showed that despite higher political uncertainty, the response to macroeconomic news in the stock market and crude oil markets has weakened and in the treasury, interest rates and foreign exchange markets have strengthened. At a time when monetary policy uncertainty is increasing, macroeconomic statements are having a significant effect on crude and fiscal markets through future fiscal policy expectations. Chang and Chawongganant (2017), in a study entitled "Market Fluctuations and Dividends: The Role of Liquidity Providers" results show that there is a negative relationship between market fluctuations and dividends and in the trading age, dividends are highly sensitive to the shock of price fluctuations. Kim and Rasingo (2017), in a study entitled "Monetary Policy Shocks and Dividends of Distressed Companies: Evidence from American public trading companies concluded that expansionary monetary shock disproportionately leads to an increase in the profits of a helpless company whose profits are less than the cost of interest and need external financing. Pariah and Vidya (2017), in a study entitled "Are Business Cycles, TechnologySpecific Investment Shocks Important for Stock Returns"? They concluded that:

(1) There is a relationship between trade shocks and stock market profits, especially at the time of financial market liberalization.

(2) Global cycles play a dominant role in the country cycle in explaining dividends.

(3) Profit rates play an important role in the interaction of dynamic business cycle and dividends.

(4) There is a relatively weak effect of technological shocks investing in the business cycle and dividends.

Mokhova and Zinker (2016) examined the effect of macroeconomic factors on the capital structure of companies in developed European countries. The results show that in all countries studied, with the exception of Greece, there is a weak and meaningless relationship 
Provide a model to identify the effect of the occurrence of business cycles on financial uncertainty in the stock market Developed countries

between GDP growth rate and capital structure. This relationship was considered very significant and positive in Greece.

\section{Methodology}

This research is an experimental research and panel data is used to test the hypothesis. The statistical population of this study is developed countries and we grouped countries based on high per capita income according to the UN human development report and data were collected from the World Bank and 21 developed countries were selected as the sample size.

In this study, using econometric models of panel data, a model was presented to identify the effect of the occurrence of business cycles on financial uncertainty in the stock market of developed countries. All data is extracted through the World Bank website and classified in Excel software, and then statistical calculations and estimates are performed using Eviews software version 10 and is used for estimation in logarithmic form in the form of the following relation: (Taghi Torabi and Taghi Hooman, 2010).

$$
\begin{aligned}
& \mathrm{LOG}(\mathrm{GAR})=\alpha_{0}+\alpha_{1} \mathrm{LOG}(\mathrm{RS} / \mathrm{RSM})_{\mathrm{it}}+\alpha_{2} \mathrm{LOG}(\mathrm{INR})_{\text {it }}+\alpha_{3} \mathrm{INF}_{\text {it }}+\alpha_{4} \mathrm{~T}_{\mathrm{t}}+\alpha_{5} \mathrm{UP}_{\text {it }}+\alpha_{6} \mathrm{DOWN}_{\text {it }} \\
& +\varepsilon_{\text {it }}
\end{aligned}
$$

The coefficients are expected to have the following symbols:

$\alpha_{>6} 0, \alpha_{5<0}, \alpha_{>4} 0, \alpha_{>3} \quad 0, \alpha_{2<0}, \alpha_{>1} \quad 0$

\section{Dependent variable:*}

\section{- Stock Market Uncertainty Index: LOG (GAR)}

This index is obtained from the growth rate variable of the S\&P 500 price index of the statistical population in the Garch method.

The S\&P index is widely used as a measure of the general level of stock prices. Because it includes both stock growth and stock value. An index is something that can be used to identify and measure the quantity, quality, change, or proof of an item. The index itself is not the goal, but indicates the realization of the goal that the indicators themselves are quantitative and qualitative (Fatemeh Ansari, 2017).

The S\&P 500 index measures the performance of active companies in the capital market, the capital market is the total value of the shares of a company that has issued, this index includes $80 \%$ of the capital market value. The $500 \mathrm{~S} \& \mathrm{P}$ is calculated based on free float investment.

\section{Independent variables:*}

\section{- Financial Lever Index Logarithm: LOG (RS / RSM)}

This index is obtained from the ratio of total credits paid by banks to individuals (total debt proxy) to the stock market value (total proxy of assets of companies present in the stock market). 


\section{- Financial Lever Index (LEV)}

Financial leverage (LEV) is used to divide the book value of total liabilities by the book value of all assets. Therefore, measuring the level of financial leverage is as follows.

$\mathrm{LEV}=\mathrm{RS} / \mathrm{RSM}$

\section{- Interest rate logarithm: LOG (INR)}

One of the monetary policy tools used by the central bank is the interest rate. It is assumed that interest rates have a negative relationship with dividends. According to the stock valuation model, when interest rates rise, the value of cash flow decreases after being discounted. Thus, the willingness to invest decreases as does stock returns (Albite, 2011).

\section{- Inflation rate: INF}

In inflationary conditions, the average nominal profit of companies increases over time. In fact, profitability has not increased, but nominal profit has increased due to inflation. When the nominal profit increases, the nominal stock price will also increase. Another effect of inflation is that it reduces the intrinsic value of each share (Sajjadi et al., 2010).

\section{- Trend variable (technical progress): $T$}

This index has been obtained from 2001-2018 to determine and change the time periods, ie the years studied in the research.

\section{- UP / DOWN business courses:}

The most common concept of business cycles is the definition of Lucas (1977).

In his article Recognizing Business Cycles, Lucas sees business cycles as recurring real GDP deviations around its long-run trend.

Thus, it is clear that the analysis of business cycles is the same as the analysis of economic fluctuations in GDP around its long-term path. When this level is higher than the trend, it is the period of prosperity and peak, and when it is lower than the trend, it is the period of depression in a business cycle.

UP: Prosperity Cycle Index (Management of Stock Investment Development Culture Fundamental Analysis)

DOWN: Recession Cycle Index (Management of Stock Exchange Investment Development Culture - Fundamental Analysis)

\section{Results}

In this study, the data for 21 developed countries, according to Table (1), have been extracted from the World Bank website during the years 2001 to 2018 using the relationships between variables and the use of panel data to investigate the effect of the occurrence of business cycles on financial uncertainty in the stock market of the target countries. 
Table 1

Study countries

\begin{tabular}{|l|l|l|l|l|l|l|}
\hline \multicolumn{9}{|c|}{ Developed countries } \\
\hline Netherlands & Australia & Singapore & Ireland & $\begin{array}{l}\text { United } \\
\text { States }\end{array}$ & Norway & Switzerland \\
\hline France & Japan & $\begin{array}{l}\text { New } \\
\text { Zealand }\end{array}$ & Belgium & Canada & Germany & Austria \\
\hline Poland & Argentina & Chile & Greece & Portugal & Spain & $\begin{array}{l}\text { South } \\
\text { Korea }\end{array}$ \\
\hline
\end{tabular}

The following steps have been performed to implement the model:

1- Static test: The significance of the model variables of high per capita income countries in the panel shows that the variables are static, so variables can be used at the level.

2- The results of Limer test showed that the model should be extracted through the panel, which is a sign of structural differences between countries.

3- The results of Hausman test showed that the model should be calculated from the random effect method, which means that the variables of invisible structural differences are unrelated to the independent variables and have no effect on them.

4- Examination of variance-covariance matrix of disruption component of the estimated model showed that:

First, the model has a heterogeneous variance (the original diameter components are not equal).

Second, the model has autocorrelation between the perturbation components of the countries (non-diagonal elements are not zero).

According to the results of paragraph 4, the SUR (seemingly unrelated equations) method was used to solve the problem of variance heterogeneity and autocorrelation simultaneously.

- Technical review the results show that:

1- The models have a suitable explanatory coefficient.

2- Statistical coefficient $\mathrm{F}$ and its probability show that $\mathrm{R} 2$ are significant.

3- Watson camera statistics, firstly, indicate the elimination of autocorrelation and secondly, indicate the goodness of the model.

4- The coefficient of financial lever index (financial structure of companies in the stock market) is positive and shows that increasing it increases insecurity in the stock market. This coefficient is higher in these countries. In other words, for one percent increase in the financial lever index, the growth rate of the S\&P index increases by 25 percent. 
5. The interest rate coefficient in countries with high per capita income is positive and increases insecurity in the stock market.

6- Inflation rate coefficient is positive and significant, but insignificant. The reason for the effect of inflation in terms of increasing production costs, increase and instability of the exchange rate and its effect on exports and imports is the inability of investors to predict the future and increase insecurity in the stock market. This coefficient shows that for one unit of growth at the inflation rate of $3 \%$, the growth rate of the $\mathrm{S} \& \mathrm{P}$ index increases.

7- The coefficient of technical progress (time passage) is negative and significant, but its value is insignificant. This means that over time, technical advances have significantly reduced the risk and insecurity of the stock market.

8- In countries with high per capita income, the effect of uncertainty boom cycles in the stock market is positive and the effect of recession cycles is negative. This can be explained by the fact that generally during a year (annual data) mainly investors buy stocks at the end of the recession cycle because buying it is considered low risk due to getting out of the recession, so its effect is negative but during the boom, the stock index grows less and sometimes stops growing. The effect of stabilizing brokerage on this issue is obvious, so during the economic boom, the risk in the stock market increases.

Table 2

the results of estimating the stock market uncertainty model from the SUR method in the data panel

\begin{tabular}{|c|c|c|c|}
\hline Variable & Coefficients & Possibility & Result \\
\hline $\mathrm{C}$ & 142.7913 & 0.0000 & Meaningful \\
\hline LOG (RS/RSM) & 0.2546 & 0.0000 & Meaningful \\
\hline LOG (INR) & 0.3087 & 0.0000 & Meaningful \\
\hline INF & 0.0318 & 0.0000 & Meaningful \\
\hline $\mathrm{T}$ & -0.0677 & 0.0000 & Meaningful \\
\hline UP & 19.8846 & 0.0000 & Meaningful \\
\hline DOWN & $\begin{array}{l}-1.6888 \\
\end{array}$ & 0.0000 & Meaningful \\
\hline $\mathrm{R}^{2}=0.9845$ & $=821.139$ & 0000 & \\
\hline
\end{tabular}

\section{Interpretation of the results of Table 2 for developed countries:-}

According to the results, the coefficients of the independent variables (financial leverage, interest rate, inflation, time, stagnant business cycles and boom business cycles) are all significant, ie their P-VALUE is less than 0.05 therefore, it can be concluded that they have a significant effect on financial uncertainty (growth rate variance of S\&P index). Also, considering that the coefficient of determination of regression model (R2) is equal to 0.984 and is close to number one, it means that Fisher test $(\mathrm{F})$ is significant (probability is less than 0.05 ) 
also, considering that the coefficient of determination of regression model (R2) is equal to 0.984 and is close to number one, it means that Fisher test (F) is significant (probability is less than 0.05 ) therefore, the regression model is justifiable and acceptable. Hypothesis $\mathrm{H} 0$ is rejected and H1 hypothesis is accepted with $95 \%$ probability in other words, business cycles have a significant effect on financial uncertainty in the stock market of developed countries.

\section{- New specification of the stock market insecurity model:}

Next, the specified model was re-specified and estimated from the complete business cycle variable instead of using recession and boom cycles. Because boom cycles and recession cycles are deviations from the long-term production process and are considered disruptive and it can increase the ambiguity in investors' forecasts, especially in long annual periods, and create risk and uncertainty in the stock market therefore, a complete trading cycle alone can cause insecurity and increase risk in the stock market.

$L O G(G A R)=\alpha_{0}+\alpha_{1} L O G(R S / R S M)_{i t}+\alpha_{2} L O G(I N R)_{i t}+\alpha_{3} I N F_{i t}+\alpha_{4} T_{t}+\alpha_{5} B C_{i t}+\varepsilon_{i}$

The results of estimating the new model with the complete business cycle variable are shown in the table below.

Technically acceptable results and coefficients of variables did not differ in terms of sign and significance compared to the previous model. But the coefficient of variation of the complete commercial cycle is significant and is a positive sign as expected. In general, the results in this section indicate a better fit of the model with complete business cycles instead of boom cycles and recession cycles.

The coefficient of variation of complete cycles in developed countries shows that for one unit of deviation of the GDP logarithm from its trend, the growth rate of the S\&P index increases by 10.11 percent.

Table 3

Results of estimating the stock market uncertainty model from the SUR method in the data panel

\begin{tabular}{|l|l|l|l|}
\hline Variable & Coefficients & Possibility & Result \\
\hline $\mathrm{C}$ & 150.0036 & 0.0000 & Meaningful \\
\hline LOG (RS/RSM) & 0.2776 & 0.0000 & Meaningful \\
\hline LOG (INR) & 0.3677 & 0.0000 & Meaningful \\
\hline INF & 0.0308 & 0.0000 & Meaningful \\
\hline T & -0.0711 & 0.0000 & Meaningful \\
\hline BC & 10.1125 & 0.0000 & Meaningful \\
\hline $\mathrm{R}^{2}=0.99$ & $\mathrm{D}-\mathrm{W}=2.0511$ & $\mathrm{~F}=16732.13$ & \\
\hline
\end{tabular}


According to the results, the coefficients of the independent variables (financial lever, interest rate, inflation, time, complete business cycle) are all significant that is, their P-VALUE is less than 0.05 , so it can be concluded that they have a significant effect on financial uncertainty (variance in the growth rate of the $\mathrm{S} \& \mathrm{P}$ index). Also, considering that the coefficient of determination of regression model (R2) is equal to 0.99 and is close to one that is, the Fisher (F) test is significant (probability less than 0.05) so the regression model is justifiable and acceptable as a result, Hypothesis $\mathrm{H} 0$ is rejected and with a 95\% probability, H1 Hypothesis is accepted, or in other words, a complete business cycle has a significant effect on financial uncertainty in the stock market of developed countries.

\section{Discussion and conclusion}

The main purpose of this study is to investigate the effect of the occurrence of business cycle variables on financial uncertainty in the stock market of developed countries, including 21 developed countries during the years 2001-2018. The research hypothesis is that business cycles have a significant effect on risk and uncertainty in the stock market of developed countries.

Using the meta-analysis method and based on the research background, a model of stock market uncertainty was specified, which was estimated from the data panel technique. Also, the variance of S\&P index growth rate, which was calculated by GARCH technique, was used as a variable of risk and uncertainty in the stock market of countries, and the HP method was used to calculate business cycles. In this subject, two regression models were estimated in the following cases:

Simultaneous existence of boom business cycles and recession business cycles in the model

\section{Complete business cycles}

According to the results of the first model, the coefficient of business cycles of recession was negative than expected in developed countries. The reason for this is that the data are annual and mainly investors buy stocks at the end of the recession because buying it is considered low risk due to getting out of the recession, so its effect is negative also, the boom cycle coefficient signals are positive contrary to expectations because the data are annual. On the other hand, during the boom, due to the stabilization brokerage and the sale of stocks to make a profit after their price increase during the boom, stock price growth is usually proven or reduced by annual data therefore, buying stocks and holding them during an economic boom increases the risk of trading in the stock market.

Also, according to the results of the second model, the coefficient of the complete commercial cycle variable has a positive and significant sign and is in line with expectations and is considered a risk and insecurity factor.

It seems that since boom cycles and recession cycles are deviations from the long-term production trend and are considered disruptive and can lead to increased ambiguity in investors' forecasts, especially in long annual periods, and create risk and uncertainty in the stock market therefore, a complete business cycle can be a better variable to show the cause of insecurity and increase risk in the stock market of countries. The results of the study were consistent with the results of Johnson (2016), Hutton et al. (2013), Moradi et al. (2012).

\section{Suggestions}


1- According to the findings of this study, the variables of boom cycles and recession cycles have a positive and significant effect on increasing risk and insecurity in the stock market therefore, it is suggested that economic policymakers increase domestic production capacity by protecting the economy from internal and external threats and fluctuations and provide the ground for increasing investment in the country's stock market and the ground for the economy to exit from the recession and reduce the duration of the recession.

2- Another way to control inflation in the country, the most important cost of which is inflation uncertainty, is to increase bank interest rates. If interest rates do not rise, investors will not invest in banks due to uncertainty and negative returns, and this will lead to negative effects on economic capital.

3- Considering the relations between inflation rates, profit rate, fluctuations of business cycles and other economic indicators as part of the market information flow, it is necessary with real stock profit in the stock market, let's not just use the price index as a criterion for evaluating the profitability of stocks or choosing new stocks.

\section{References}

Afshari, Z., Tavaklian, H., \& Bayat, M. (2018). Investigating the effect of total stock price index shock on macroeconomic variables using DSGE approach. Quarterly Journal of Economic Research (Sustainable Growth and Development), 18(2), 103-81.

Albaity, M. (2011). Impact of the Monetary Policy Instrument on Islamic Stock Market Index Return, Economics open- Assessment E-journal, 7, 89-105.

Alexander Kurov, R. S. (2018). Monetary policy uncertainty and the market reaction to macroeconomic news. Journal of Banking and Finance, 86, 127-142.

Anna, M., Sotiria, T., Anna, T. \& L. Alexandros. (2015). The Relationship between Business Cycles and Capital Structure Choice: The Case of the International Shipping Industry. The Journal of Economic Asymmetries, 12(2), 92-99.

Aquarius, M., Dargahi, H., \& Wisdom, M. (2017). The effect of business cycle on the relationship between profitability and financial leverage. Financial Accounting Research, 9(3), 65-49.

Azinfar, K., \& Zaghi Saro Kalaei, F. (2015). The effect of financial lever on the performance of pharmaceutical companies listed on the Tehran Stock Exchange. The Second National Conference and the Second International Conference on Management and Accounting of Iran, Hamedan. Permanent Secretariat of the Conference.

Chung, K. H., \& Chuwonganant, C. (2017). Market volatility and stock returns: the role of liquidity providers. Journal of Financial Markets, 15, 67-79.

Hosseini, S., \& Mosallanejad, V. (2017). Investigating the effect of financial performance and business cycle on the capital structure of companies operating in the Tehran Stock Exchange. Quarterly Journal of Management and Accounting Studies, 3(3), 121-108.

Imam Verdi, Gh. (2014). Investigating the threshold and asymmetric effect of leverage ratio on the profitability of companies operating in the Tehran Stock Exchange. Financial Economics Quarterly, 11(93), 81-57.

Kaviani, Gh. (2017). Comparison of the efficiency of financial ratios based on cash method and accrual method in predicting financial distress of companies listed on the Tehran Stock 
Exchange. Stock Exchange Quarterly, 15, 205-199.

Kim, S. T., \& Rescigno, L. (2017). Monetary policy shocks and distressed firms' stock returns: Evidence from the publicly traded US firms. Economics Letters, 160, 91-94.

Marandu, K. R., \& A. B. Sibindi. (2016). Capital Structure and Profitability: an Empirical Study of South African Banks. Corporate Ownership \& Control, 14(1), 8-19.

Minooi, M., \& Ismaili, M. (2016). Investigating the relationship between financial leverage and operating leverage with systematic risk in companies listed on the Tehran Stock Exchange. Sixth International Conference on Accounting and Management and Third Conference on Entrepreneurship and Open Innovation.

Prabheesh, K. P., \& Vidya, C. T. (2017). Do business cycles, investment-specific technology shocks matter for stock returns. Economic Modelling, 18, 145-160.

Sajjadi, S. H., Farazmand, H., \& Sofieh, A. (2010). "Study of the relationship between macroeconomic variables and cash return index of stocks in Tehran Stock Exchange". Journal of Economic Sciences, 2(39), 56-67.

Tehrani, M. (2008). Investigating the economic variables affecting the stock price index of Tehran Stock Exchange. Journal of Planning and Budgeting, 40, 31-60.

Torabi, T., \& Hooman, T. (2010). The effects of macroeconomic variables on the returns of the Tehran Stock Exchange. Quarterly Journal of Economic Modeling, 4(1), 11-19. 